\title{
ANALISIS KINERJA KEUANGAN PASAR DAERAH: STUDI PENGEMBANGAN POTENSI MENUJU BUMD
}

\author{
Nanik Wahyuni \\ Fakkultas Ekonomi UIN Maliki Malang \\ nanik.wahyuni@yahoo.co.id \\ HP. 081233381656
}

\begin{abstract}
The objective of this research is to describe financial performance of traditional market on local market at Pasuruan Regency. The evaluation of financial performance based on economic principle, efficient and effectively that used to analysis development potency to be a region enterprise. This research used an anual financial report and management report in 2007 untill 2011. The analysis result describe that assets has owned by traditional market can be a base capital become a region enterprise of market with pay attention increased financial performance. Based on the evaluation value for money concluded that financial performance on traditional market is economic, effective but inefficient. Based on the result of financial ratio analysis conclude that traditional market at Pasuruan Regency was autonomous yet, low activity, low capital expenses, the growth of expenditure is always higher than the growth of income, but the equity ratio gives diskription that traditional market can pay by self to get his assets.
\end{abstract}

Key Words : Financial Performance, Traditional Market, Lokal market.

Organisasi dan manajemen pemerintah daerah sangat memerlukan dukungan tersedianya sumber-sumber keuangan daerah yang memadai dan stabil guna penyelenggaraan pemerintahan dan pembangunan di daerah. Anggaran Pendapatan dan Belanja Daerah (APBD) yang disusun setiap tahun merupakan sumber dana pemerintah daerah dalam rangka mengelola daerahnya dan meningkatkan kesejahteraan masyarakatnya melalui kegiatan pembangunan di berbagai bidang. Kemandirian suatu daerah bisa dilihat dari besarnya dana yang berasal dari Pendapatan Asli Daerah (PAD). Semakin besar PAD dalam APBD akan semakin kuat suatu daerah dalam membiayai penyelenggaraan pemerintahan dan pembangunan daerahnya.

Pendapatan Asli Daerah sebagaimana dimaksud dalam Undang-undang Nomor 33 tahun 2004 tersebut di atas secara terinci terdiri dari : hasil pajak daerah; 
hasil retribusi daerah; hasil pengelolaan kekayaan daerah yang dipisahkan; lain-lain usaha daerah yang sah. Hasil pengelolaan kekayaan daerah yang dipisahkan sebagai salah satu sumber PAD antara lain dari perusahaan daerah atau lebih dikenal dengan sebutan Badan Usaha Milik Daerah (BUMD). Perusahaan daerah mempunyai posisi strategis sebagai pendukung dana bagi pemerintah daerah melalui sumbangan laba yang dihasilkannya, tetapi hingga saat ini keberadaan perusahaan daerah belum banyak mendapat perhatian.

Salah satu pelayanan publik yang dimiliki oleh banyak daerah adalah pasar daerah. Pasar daerah mempunyai peran yang sangat komplek selaku pelaku ekonomi, pelayan publik dan sekaligus pendukung kelancaran pembangunan daerah melalui retribusi pasar yang dihasilkannya sebagai salah satu sumber PAD. Peraturan Menteri Dalam Negeri nomor 13 Tahun 2006 tentang pengelolaan keuangan daerah menyatakan bahwa pengelolaan pasar daerah bukanlah merupakan urusan wajib pemerintah daerah, tetapi merupakan urusan pilihan dan bagian dari perdagangan. Peraturan Pemerintah Nomor 41 tahun 2011 tentang organisasi perangkat daerah tidak menyebutkan keberadaan Dinas Pasar sebagai satuan kerja yang mengelola pasar daerah. Berdasarkan kedua peraturan tersebut, di masa yang akan datang pasar daerah diharapkan tidak selalu bergantung kepada pemerintah daerah untuk dapat menjaga kelangsungan hidupnya (survival), bahkan dimungkinkan bisa tumbuh (growth) dan berkembang menjadi perusahaan daerah yang mampu menghasilkan keuntungan (profitability), sehingga dapat ikut berperan secara nyata dalam memberikan kontribusi pada Pendapatan Asli Daerah.

Penelitian ini bertujuan untuk menganalisis kondisi faktor-faktor yang mendukung kinerja keuangan pasar daerah; untuk mengevaluasi ekonomi, efisiensi dan efektivitas kinerja keuangan pasar daerah; serta untuk menganalisis potensi pengembangan pengelolaan pasar daerah menjadi Perusahaan Daerah Pasar ditinjau dari sudut kinerja keuangan.

\section{Keuangan Daerah}

Berdasarkan Peraturan Pemerintah Nomor 58 Tahun 2005 tentang Pengelolaan Keuangan Daerah pada Bab 1 Ketentuan Umum Pasal 1 ayat 5 
pengertian keuangan daerah adalah semua hak dan kewajiban daerah dalam rangka penyelenggaraan pemerintahan daerah yang dapat dinilai dengan uang termasuk didalamnya segala bentuk kekayaan yang berhubungan dengan kewajiban daerah tersebut. Pada ayat 6 dijelaskan bahwa pengertian pengelolaan keuangan daerah adalah keseluruhan kegiatan yang meliputi perencanaan, pelaksanaan, penatausahaan, pelaporan, pertanggungjawaban dan pengawasan keuangan daerah. Undang-undang Nomor 32 tahun 2004 tentang Pemerintahan Daerah mengakibatkan adanya perubahan yang sangat mendasar dalam pengelolaan keuangan daerah, termasuk di bidang manajemen atau pengelolaan keuangan daerah. Hal tersebut mengingat manajemen keuangan daerah merupakan alat yang digunakan untuk mangurus dan mengatur rumah tangga pemerintah daerah (Halim 2002:2).

Perubahan manajemen keuangan daerah secara tegas ditandai dengan diberlakukannya Undang-undang Nomor 17 Tahun 2007 tentang Keuangan Negara. Implementasi atas undang-undang tersebut diatur melalui Peraturan pemerintah Nomor 58 Tahun 2005 tentang Pengelolaan Keuangan Daerah dan Peraturan Pemerintah Nomor 24 Tahun 20065 tentang Standar Akuntansi Pemerintahan. Halim (2002:4), mengkaji adanya beberapa pergeseran manajemen keuangan daerah yang terjadi dalam pengelolaan APBD, yaitu akuntabilitas vertikal menjadi horizontal dan vertical, penyusunan anggaran tradisional menjadi anggaran kinerja, pengendalian dan audit keuangan menjadi pengendalian dan audit keuangan dan kinerja, penggunaan dana APBD secara ekonomi, efisien dan efektif, adanya pusat pertanggungjawaban dan penerapan sistem keuangan dari pembukuan menjadi akuntansi.

\section{Perusahaan Daerah}

Pasal 10 ayat 1 Undang-undang Nomor 32 tahun 2004 tentang pemerintahan daerah, menyatakan bahwa pemerintah daerah menyelenggarakan urusan pemerintahan yang menjadi kewenangannya, kecuali urusan pemerintahan yang ditentukan menjadi urusan pemerintah pusat. Selanjutnya didalam pasal 155 ayar 1 menyatakan bahwa menyelenggarakan urusan pemerintahan yang menjadi 
kewenangan daerah didanai dari dan atas beban anggaran pendapatan dan belanja daerah.

Pasal 5 ayat 2 Undang-Undang Nomor 33 tahun 2004 tentang Perimbangan Keuangan antara Pemerintah Pusat dan Pemerintah Daerah menyatakan bahwa pendapatan daerah bersumber dari : pendapatan asli daerah, dana perimbangan dan lain-lain pendapatan. Pada Pasal 6 ayat 1 Undang-undang tersebut menyatakan bahwa pendapatan asli daerah bersumber dari : pajak daerah, retribusi daerah, hasil pengelolaan kekayaan daerah yang dipisahkan dan lain-lain pendapatan asli daerah yang sah. Undang-Undang tersebut membuka peluang baru bagi pemerintah daerah untuk melakukan reformasi dibidang pelayanan publik yang lebih proaktif terhadap kebutuhan-kebutuhan yang diperlukan masyarakat daerah setempat. Pemerintah daerah juga diberi kewenangan melalui pengelolaan kekayaan daerah yang dipisahkan untuk mengelola kegiatan usaha yang mampu memberikan kontribusi nyata bagi pendapatan asli daerah sehingga dapat meningkatkan kemandiriannya dalam pembangunan daerah.

Kekayaan daerah yang dipisahkan berupa kegiatan usaha yang dikelola oleh pemerintah daerah dalam bentuk perusahaan daerah. Berdasarkan Undang-undang Nomor 17 Tahun 2007 tentang Keuangan Negara yang dimaksud dengan perusahaan daerah adalah badan usaha yang seluruh atau sebagian modalnya dimiliki oleh pemerintah daerah. Sumarni (1995:42) menjelaskan bahwa perusahaan daerah adalah perusahaan yang modal/sahamnya dimiliki oleh pemerintah daerah, dimana kekayaan perusahaan dipisahkan dari kekayaan daerah. Tujuan Perusahaan daerah adalah memperoleh laba yang nantinya akan digunakan untuk membangun daerahnya.

\section{Kinerja Keuangan Daerah}

Munculnya berbagai kritikan terhadap kenerja pemerintah sebagai organisasi sektor publik menimbulkan gerakan untuk melakukan reformasi manajemen sektor publik. Mahmudi (2005:1) menjelaskan bahwa tekanan masyarakat terhadap organisasi sektor publik untuk memperbaiki kinerjanya mendorong dibangunnya sistem manajemen organisasi sektor publik yang berbasis 
kinerja. Evaluasi hasil kinerja sektor publik menjadi sangat penting karena evaluasi kinerja pemerintah berkaitan erat dengan akuntabilitas publik. Akuntabilitas publik adalah kewajiban pemerintah untuk mengelola sumber daya, melaporkan dan mengungkapkan segala aktivitas dan kegiatan yang berkaitan dengan penggunaan sumber daya publik kepada masyarakat sebagai pemberi mandat (Mahmudi 2005:9).

Salah satu bentuk akuntabilitas publik adalah akuntabilitas finansial, yaitu pertanggungjawaban lembaga-lembaga sektor publik atas penggunaan uang publik secara ekonomi, efisien, efektif, tidak ada pemborosan dan kebocoran dana serta korupsi. Akuntabilitas finansial menekankan pada ukuran anggaran dan finansial. Akuntabilitas finansial mengharuskan lembaga-lembaga publik membuat laporan keuangan untuk menggambarkan kinerja finansial organisasi sektor publik kepada pihak luar atas penggunaan APBD. Mengingat Dinas Pasar merupakan Satuan Kerja Pemerintah Daerah yang memberikan pelayanan publik, maka penilaian terhadap kinerja keuangan dinas pasar diperlakukan sama dengan penilaian terhadap kinerja keuangan daerah.

\section{Analisis Rasio Keuangan Daerah}

Halim (2002:127) mengkaji analisis keuangan sebagai suatu usaha mengidentifikasi ciri-ciri keuangan berdasarkan laporan keuangan yang tersedia. Bagi lembaga komersial, analisis rasio keuangan terdiri dari : (a) Rasio likuiditas, yaitu rasio yang menggambarkan kemampuan perusahaan untuk memenuhi kewajibanya dengan segera; (b) Rasio leverage, yaitu rasio yang mengukur perbandingan dana yang disediakan oleh pemilik dengan dana yang dipinjam dari kreditor; (c) Rasio aktivitas, yaitu rasio yang digunkan untuk mengukur efektif tidaknya perusahaan didalam menggunakan sumber daya yang dimiliki; (d) Rasio profitabilitas, yaitu rasio yang digunakan untuk mengukur kemampuan perusahaan dalam menghasilkan laba.

Penggunaan analisis rasio keuangan pada pemerintah daerah khususnya terhadap laporan keuangan daerah belum banyak dilakukan. Meskipun demikian, dalam rangka pengelolaan keuangan daerah yang transparan, jujur, demokratis, 
efektif dan akuntabel perlu dilakukan analisis rasio terhadap laporan keuangan daerah. Analisis rasio keuangan terhadap laporan keuangan daerah dapat digunakan untuk: (a) menilai kemandirian keuangan daerah dalam membiayai penyelenggaraan otonomi daerah; (b) mengukur efektivitas dan efisiensi dalam merealisasikan pendapatan daerah; (c) mengukur sejauhmana aktivitas pemerintah daerah dalam membelanjakan pendapatan daerahnya; (d) mengukur kontribusi masing-masing sumber pendapatan dalam pembentukan pendapatan daerah; (e) melihat pertumbuhan/perkembangan perolehan pendapatan dan pengeluaran yang dilakukan selama periode waktu tertentu.

Halim (2002:128) menjelaskan beberapa analisis rasio keuangan yang dapat digunakan dan dikembangkan untuk menganalisis pengelolaan keuangan daerah berdasarkan data keuangan yang bersumber dari laporan realisasi anggaran, neraca dan laporan arus kas adalah sebagai berikut:

a. Rasio kemandirian keuangan daerah

Kemandirian keuangan daerah menunjukkan kemampuan pemerintah daerah dalam membiayai sendiri kegiatan pemerintahan, pembangunan dan pelayanan kepada masyarakat. Kemandirian keuangan daerah ditunjukkan oleh besar kecilnya pendapatan asli daerah dibandingkan dengan pendapatan daerah yang bersumber dari sumber yang lain, misalnya bantuan pemerintah pusat atau dari pinjaman.

\begin{tabular}{|ll|}
\hline \multirow{2}{*}{ Rasio Kemandirian $=$} & Pendapatan Asli Daerah \\
& --ontuan Pemerintah Pusat/ \\
& Propinsi/Pinjaman \\
\hline
\end{tabular}

Rasio kemandirian menggambarkan ketergantungan daerah terhadap sumber dana ekstern. Semakin tinggi rasio kemandirian mengandung arti bahwa tingkat ketergantungan daerah terhadap bantuan pihak ekstern (terutama pemerintah pusat dan propinsi) semakin rendah, dan demikian pula sebaliknya. 
Rasio kemandirian juga menggambarkan tingkat partisipasi masyarakat dalam pembangunan daerah. Semakin tinggi rasio kemandirian, semakin tinggi partisipasi masyarakat dalam membayar pajak dan retribusi daerah yang merupakan komponen utama pendapatan asli daerah.

b. Rasio aktivitas

Rasio aktivitas menggambarkan bagaimana keserasian pemerintah daerah dalam mengalokasikan dananya terhadap belanja langsung dan belanja tidak langsung. Belanja langsung adalah belanja pegawai, belanja barang dan jasa, belanja modal. Belanja tidak langsung adalah belanja gaji, belanja subsidi, belanja hibah, belanja bagi hasil, belanja bantuan keuangan, belanja tidak tersangka, dan belanja bunga.

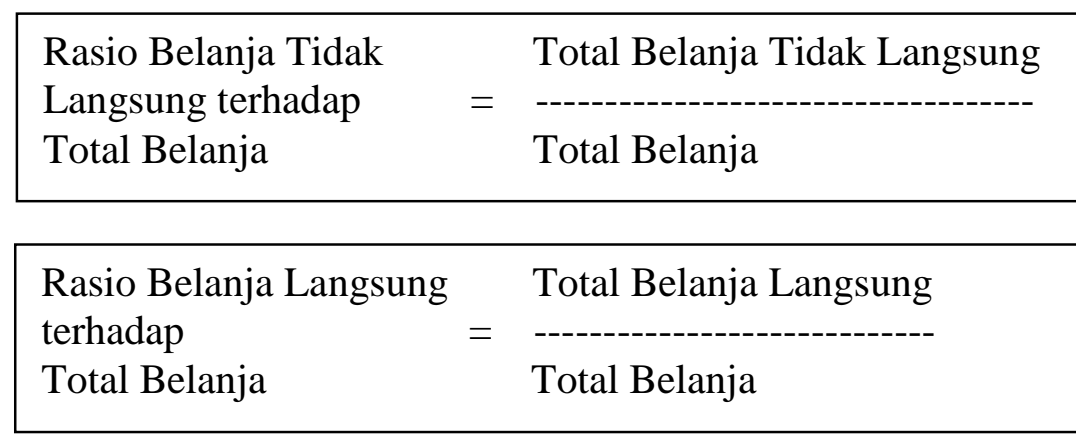

Angka rasio belanja langsung terhadap total belanja diatas 50 persen menunjukkan kecenderungan anggaran pemerintah daerah lebih banyak digunakan untuk membiayai kegiatan-kegiatan penyediaan sarana prasarana ekonomi masyarakat yang semakin baik dan sebaliknya.

c. Rasio belanja modal terhadap total belanja

Rasio ini mengukur persentase jumlah realisasi belanja untuk kegiatan penmbangunan fisik (belanja modal) dibandingkan dengan seluruh realisasi belanja.

\begin{tabular}{|c|c|}
\hline Rasio Belanja Modal & Total Belanja Modal \\
\hline Total Belanja & Total Belanja \\
\hline
\end{tabular}


Angka rasio diatas $50 \%$ memperlihatkan kecenderungan realisasi belanja anggaran pemerintah daerah lebih banyak digunakan untuk kegiatan pembangunan fisik (belanja modal).

d. Rasio ekuitas dana terhadap aset (Ratio Ekuitas)

Rasio ini menggambarkan kemampuan pemerintah daerah untuk membiayai pembangunan daerahnya.

\begin{tabular}{|ll|}
\hline \multirow{2}{*}{ Rasio Ekuitas $=$} & Total Ekuitas Dana \\
& ------------------ \\
& Total Aset \\
\hline
\end{tabular}

Rasio diatas $100 \%$ menunjukkan bahwa pemerintah daerah dapat membiayai kegiatan pembangunan dengan kemampuan sendiri.

e. Rasio Pertumbuhan

Rasio pertumbuhan mengukur seberapa besar kemampuan pemerintah daerah dalam mempertahankan dan meningkatkan keberhasilan yang telah dicapai dari suatu periode ke periode berikutnya. Komponen-komponen sumber pendapatan dan pengeluaran pemerintah diukur prosentase perkembangannya dari satu periode ke periode berikutnya selama beberapa periode. Diketahuinya pertumbuhan untuk masing-masing komponen sumber pendapatan dan pengeluaran, maka dapat dipergunakan untuk mengevaluasi potensi-potensi mana yang perlu mendapat perhatian.

\section{Evaluasi Kinerja Value for Money}

Penilaian terhadap kinerja sektor publik harus dilakukan secara obyektif. Akuntabilitas sebagai pertanggungjawaban kinerja keuangan sektor publik bukanlah sekedar kemampuan menunjukkan bagaimana uang rakyat dibelanjakan, akan tetapi meliputi kemampuan menujukkan bahwa uang publik tersebut telah dibelanjakan secara ekonomi, efisien dan efektif atau yang dikenal dengan value for money. Halim (2002:5) mengkaji bahwa pemerintah dalam mencari dana maupun menggunakan dana dituntut untuk menerapkan prinsip ekonomi, efisiensi 
dan efektif (3 E). Hal tersebut mendorong pemerintah untuk selalu memperhatikan tiap rupiah dana yang diperoleh dan digunakan. Mahmudi (2005:89) menjelaskan, value for money memiliki pengertian penghargaan terhadap nilai uang. Pengertian tersebut mengandung makna setiap rupiah harus dihargai secara layak dan digunakan sebaik-baiknya. Evaluasi kinerja value for money adalah evaluasi kinerja untuk berdasarkan ekonomi, efisiensi dan efektivitas suatu program dan kegiatan organisasi publik. Evaluasi ekonomi, efisien dan efektif dilakukan terhadap komponen masukan (input), hasil yang diharapkan (output) dan komponen hasil yang dicapai (outcome).

\section{a. Evaluasi Ekonomi}

Evaluasi ekonomi berfokus pada masukan (input), artinya ekonomi hanya mempertimbangkan masukan (input) yang digunakan, yaitu besarnya biaya yang dikeluarkan untuk memperoleh unit input. Ekonomi memiliki pengertian bahwa pelaksanaan pembelian sumber daya input dengan kualitas dan kuantitas tertentu diperoleh dengan harga yang terbaik, yaitu harga yang paling rendah dari harga yang ada di pasar. Secara matematis, ekonomi merupakan perbandingan antara input dengan nilai rupiah untuk memperoleh input tersebut.

Ekonomi $=$ Input
Harga Input $(\mathrm{Rp}$.

\section{b. Evaluasi Efisiensi}

Evaluasi berdasar efisiensi berfokus pada hasil yang diharapkan (output), artinya efisiensi terkait dengan hubungan antara output berupa barang atau jasa yang dihasilkan dengan input yang dipergunakan untuk menghasilkan output tersebut. Suatu organisasi dikatakan efisien apabila mampu menghasilkan output tertentu dengan input yang serendah-rendahnya. Secara matematis, efisiensi merupakan perbandingan antara output dengan input. 


\begin{tabular}{|cc|}
\hline \multirow{2}{*}{ Efisiensi $=$ Output } \\
& Input \\
\hline
\end{tabular}

\section{c. Evaluasi Efektivitas}

Pelaksanaan pengelolaan keuangan daerah diharapkan dapat mecapai tujuan dan sasaran. Evaluasi efektivitas berfokus pada hasil yang sesungguhnya dicapai (outcome), artinya efektivitas terkait dengan hubungan antara hasil yang sesungguhnya dicapai dengan hasil yang diharapkan (output), atau dengan kata lain hubungan antara realisasi hasil dengan target hasil. Evaluasi efektivitas perlu dilakukan untuk melihat apakah hasil pelaksanaan program/kegiatan suatu organisasi telah mecapai tujuan yang telah ditetapkan sebelumnya atau tidak. Secara matematis, efektivitas merupakan perbandingan antara outcome (hasil yang dicapai) dengan output (hasil yang diharapkan).

\begin{tabular}{|c|c|}
\hline Efektivitas $=$ Outcome \\
& Output \\
\hline
\end{tabular}

\section{METODE}

Pendekatan yang akan digunakan dalam penelitian ini adalah pendekatan diskriptif dengan teknik observasi lapangan dan studi kepustakaan. Observasi lapangan dalam bentuk kunjungan ke Dinas Pasar di Kabupaten Pasuruan untuk mengumpulkan data-data sekunder yang berkaitan dengan kinerja keuangan. Studi kepustakaan dimaksudkan untuk memperoleh literatur, peraturan perundangundangan, dan hasil penelitian sebelumnya yang sesuai dengan penelitian ini yang digunakan sebagai landasan teori dalam menganalisis data sekunder yang diperoleh tersebut. Ruang lingkup penelitian ini di bidang akuntansi sektor publik mengenai analisis faktor-faktor yang mendukung kinerja keuangan pasar daerah yang berhubungan dengan rasio keuangan berupa : rasio kemandirian, rasio aktivitas, 
rasio belanja modal, rasio ekuitas dan rasio pertumbuhan serta evaluasi kinerja Value for Money berupa evaluasi : ekonomi, efisiensi dan efektivitas.

\section{Variabel Penelitian}

Untuk dapat mendefinisikan operasional dari variabel-variabel yang diteliti, maka terlebih dahulu harus dirumuskan batasan-batasan konseptual sebagai berikut:

\section{a. Rasio keuangan}

Halim (2002:128) menjelaskan definisi konseptual tentang variabel-variabel rasio keuangan sebagai berikut: (1) Rasio kemandirian keuangan pasar daerah, kemandirian keuangan pasar daerah menunjukkan kemampuan pasar daerah dalam membiayai sendiri kegiatan pengelolaan dan pelayanan kepada masyarakat. (2) Rasio aktivitas, rasio aktivitas menggambarkan bagaimana pasar daerah dalam mengalokasikan dananya terhadap belanja langsung atau belanja tidak langsung. Belanja langsung adalah belanja pegawai, belanja barang dan jasa, serta belanja modal. Belanja tidak langsung adalah belanja gaji. (3) Rasio belanja modal terhadap total belanja, rasio belanja modal menggambarkan seberapa besar Dinas Pasar mengalokasikan dananya untuk belanja modal berupa kegiatan pembangunan fisik pasar daerah. (4) Rasio ekuitas dana terhadap aset (Rasio Ekuitas), rasio ekuitas bertujuan untuk menilai kemampuan pasar daerah untuk membiayai pembangunan dan rehabilitasi aset pasar berdasarkan ekuitas dana yang dimiliki. (5) Rasio pertumbuhan, rasio pertumbuhan mengukur seberapa besar kemampuan pasar daerah dalam mempertahankan dan meningkatkan keberhasilan yang telah dicapai dari satu periode ke periode berikutnya. Diketahuinya pertumbuhan masing-masing komponen sumber pendapatan dan belanja, dapat digunakan untuk mengevaluasi potensi-potensi yang perlu mendapat perhatian.

\section{b. Evaluasi kinerja Value for Money}

Mahmudi (2005:89) menjelaskan definisi konseptual tentang variabelvariabel evaluasi kinerja value for money sebagai berikut: (1) Ekonomi, evaluasi 
ekonomi terkait dengan evaluasi sejauh mana pasar daerah dapat meminimalisir penggunaan sumber daya yang dimiliki berupa anggaran belanja dalam rangka pelaksanaan program/kegiatan, yaitu dengan menghindari pengeluaran yang boros dan tidak produktif. (2) Efisiensi, evaluasi efisiensi terkait dengan evaluasi sejauhmana pasar daerah dapat mecapai target pelaksanaan program/kegiatan yang telah ditetapkan dengan penggunaan sumber daya yang serendah-rendahnya. (3) Efektivitas, evaluasi efektivitas terkait dengan evaluasi sejauh mana pencapaian hasil pelaksanaan program/kegiatan pasar daerah dari target hasil yang telah ditetapkan sebelumnya.

\section{Teknik Analisis Data}

Data sekunder yang diperoleh dari hasil observasi lapangan di Dinas Pasar akan dianalisis melalui beberapa tahapan sebagai berikut: (a) Melakukan analisis rasio keuangan dengan teknik analisis data terhadap variabel-variabel rasio keuangan berupa analisis rasio kemandirian keuangan pasar daerah, analisis rasio aktivitas, analisis rasio belanja modal terhadap total belanja, analisis rasio ekuitas dana terhadap aset, dan analisis rasio pertumbuhan. (b) Melakukan evaluasi kinerja berdasarkan Value for Money. (c) Mendiskripsikan hasil analisis rasio dan evaluasi kinerja value for money guna melihat kinerja keuangan pasar daerah. (d) Menginterprestasikan hasil analisis rasio dan evaluasi kinerja value for money guna melihat potensi pengembangan pengelolaan pasar daerah menjadi perusahaan daerah pasar.

\section{HASIL DAN PEMBAHASAN}

Hasil penelitian berupa data yang kami peroleh dari observasi lapangan di Dinas Pasar tersebut diatas dianalisis melalui beberapa tahapan sebagai berikut. 
Tabel 1

Rekapitulasi Hasil Analisis Rasio dan Evaluasi Berdasarkan Value for Money Dinas Pasar tahun 2007 s/d 2011

\begin{tabular}{|c|c|c|c|c|c|c|c|c|}
\hline \multirow{2}{*}{ No. } & \multirow{2}{*}{ Uraian } & \multirow{2}{*}{$\begin{array}{c}\text { Standar } \\
\text { Wajar }(\%)\end{array}$} & \multicolumn{5}{|c|}{ Hasil Analisis ( \%) } & \multirow{2}{*}{ Keterangan } \\
\hline & & & 2007 & 2008 & 2009 & 2010 & 2011 & \\
\hline A. & Analisis Rasio Keuangan & & & & & & & \\
\hline 1. & Rasio Kemandirian & $>100,00$ & 72,31 & 69,49 & 77,11 & 52,69 & 40,40 & Belum mandiri \\
\hline 2. & Rasio Aktivitas & $>50,00$ & 23,41 & 27,91 & 27,33 & 24,75 & 27,17 & Aktivitas rendah \\
\hline 3. & Rasio Belanja Modal & $>50,00$ & 3,82 & 4,47 & 3,00 & 1,07 & 1,55 & Penyediaan sarana fisik rendah \\
\hline 4. & Rasio Ekuitas & $>100,00$ & & & & & 100,00 & Dapat membiayai sendiri \\
\hline 5. & Rasio Pertumbuhan Pendapatan & Positif & & 2,17 & 1,51 & 2,87 & 1,15 & Pertumbuhan positif \\
\hline . & Rasio Pertumbuhan Belanja & Positif & & 4,57 & $-4,42$ & 29,15 & 21,30 & Pertumbuhan positif \\
\hline$B$. & Evaluasi Value for Money & & & & & & & \\
\hline 1. & Evaluasi Ekonomi & $<100$ & 98,13 & 99,09 & 98,23 & 98,70 & 98,39 & Ekonomi \\
\hline 2. & Evaluasi Efisiensi & $>100$ & 41,96 & 41,00 & 43,54 & 34,51 & 28,78 & Tidak Efisien \\
\hline 3. & Evaluasi Efektivitas & $>100$ & 100,98 & 101,08 & 100,34 & 100,50 & 101,14 & Efektif \\
\hline
\end{tabular}




\section{Potensi Pengelolaan Pasar Daerah Menjadi Perusahaan Daerah Pasar}

Perusahaan Daerah Pasar sebagai Badan Usaha Milik Daerah pengelolaannya harus dipisahkan dari kekayaan daerah, sehingga harus dapat membiayai sendiri seluruh pengeluarannya tanpa bantuan dana dari pemerintah daerah, bahkan sebaliknya sebagai perusahaan daerah harus berorientasi pada upaya memperoleh laba yang pada akhirnya sebagian dari laba tersebut harus disetor kepada daerah. Hasil analisis rasio ekuitas pasar daerah sebesar $100 \%$ menggambarkan bahwa pasar daerah dapat membiayai sendiri kegiatan pemenuhan kebutuhan asetnya. Ketersediaan aset berupa sarana prasarana fisik pada 15 pasar daerah merupakan modal awal yang telah lama ada sehingga pemerintah daerah tidak perlu mengeluarkan dana lagi untuk investasi awal berupa pembangunan pasar baru. Ditinjau dari hasil analisis rasio ekuitas tersebut maka pasar daerah berpotensi untuk dikembangkan pengelolaannya menjadi Perusahaan Daerah Pasar.

Hasil analisis rasio kemandirian pasar daerah tahun 2007 sampai dengan 2011 seluruhnya dibawah standar wajar $100 \%$ menggambarkan pasar daerah masih belum mandiri. Ketergantungan terhadap bantuan dana dari pemerintah daerah untuk membiayai belanja tidak langsung dan belanja langsung sangat tinggi dan semakin meningkat sehingga potensinya sangat kecil untuk dapat dikembangkan pengelolaannya menjadi Perusahaan Daerah Pasar.

Hasil analisis rasio aktivitas Dinas Pasar dalam mengelola pasar daerah tahun 2007 sampai dengan tahun 2011 seluruhnya dibawah standar wajar $50 \%$ menggambarkan bahwa aktivitas Dinas Pasar masih rendah. Rendahnya aktivitas tersebut dikarenakan sebagian besar dana digunakan untuk belanja tidak langsung berupa gaji pegawai sehingga hanya sebagian kecil dana digunakan untuk aktivitas dalam rangka meningkatkan pendapatan dan akibatnya kemungkinan untuk memperoleh laba menjadi sangat kecil. Kondisi tersebut menggambarkan bahwa pasar daerah potensinya sangat kecil untuk dapat dikembangkan pengelolaannya menjadi Perusahaan Daerah Pasar.

Hasil analisis rasio belanja modal Dinas Pasar dalam mengembangkan pasar daerah tahun 2007 sampai dengan tahun 2011 seluruhnya dibawah standar wajar $50 \%$, bahkan dibawah $5 \%$ menggambarkan bahwa selama 5 (lima) tahun 
terakhir pembangunan sarana fisik pasar daerah sangat kecil sekali, bahkan tidak ada pembangunan los, toko, kios dan bedak baru sehingga kemungkinan peningkatan pendapatan retribusi sangat kecil dan akibatnya kemungkinan untuk memperoleh laba juga sangat kecil. Kondisi tersebut menggambarkan bahwa pasar daerah potensinya sangat kecil untuk dapat dikembangkan pengelolaannya menjadi Perusahaan Daerah Pasar.

Rasio pertumbuhan pendapatan dan belanja Dinas Pasar dalam mengelola pasar daerah tahun 2007 sampai dengan tahun 2011 positif, pertumbuhan pendapatan tahun 2007 sampai dengan tahun 2011 selalu lebih rendah dari pertumbuhan belanja. Hasil analisis tersebut menggambarkan bahwa pasar daerah memiliki potensi untuk meningkatkan pendapatan retribusi tetapi peningkatan pengeluarannya selalu lebih besar sehingga kemungkinan untuk memperoleh laba juga sangat kecil. Kondisi tersebut menunjukkan bahwa pasar daerah potensinya sangat kecil untuk dapat dikembangkan pengelolaannya menjadi Perusahaan Daerah Pasar.

Evaluasi berdasarkan ekonomi terhadap pengelolaan keuangan Dinas Pasar pada tahun 2007 sampai dengan tahun 2011 selalu dibawah standar wajar $100 \%$. Hasil tersebut menujukkan bahwa Dinas Pasar bersifat ekonomis dalam mengelola belanjanya, tetapi prosentase ekonomi tersebut sangat kecil dan dipengaruhi oleh belanja tidak langsung berupa relaisasi pembayaran gaji pegawai. Tabel 3 menunjukan bahwa anggaran untuk belanja gaji pegawai setiap tahun selalu naik dan realisasi belanja gaji pegawai selalu lebih besar dari anggaran tahun sebelumnya, sehingga walaupun hasil evaluasi menunjukkan ekonomis tetapi sebenarnya secara nominal realisasi belanja selalu naik dan akibatnya kemungkinan untuk memperoleh laba juga sangat kecil. Kondisi tersebut menggambarkan bahwa pasar daerah potensinya sangat kecil untuk dapat dikembangkan pengelolaannya menjadi Perusahaan Daerah Pasar.

Hasil evaluasi berdasarkan efisiensi terhadap pengelolaan keuangan Dinas Pasar dalam mengelola pendapatan dan belanja tahun 2007 sampai dengan tahun 2011 seluruhnya dibawah standar wajar $100 \%$, bahkan dibawah $50 \%$ menunjukkan bahwa kegiatan dalam memperoleh pendapatan dilaksanakan dengan tidak efisien, karena belanja selalu lebih besar dari pendapatnnya 
sehingga kemungkinan untuk memperoleh laba juga semakin kecil. Kondisi tersebut menggambarkan bahwa pasar daerah potensinya sangat kecil untuk dapat dikembangkan pengelolaannya menjadi Perusahaan Daerah Pasar.

Hasil evaluasi berdasarkan efektivitas Dinas Pasar pada tahun 2007 sampai dengan tahun 2011 selalu diatas standar wajar $100 \%$, menunjukkan bahwa Dinas Pasar efektif dalam mencapai target pendapatan retribusinya. Walaupun realisasi pendapatan selalu lebih besar dari targetnya tetapi prosentase efektivitas tersebut sangat kecil (tertinggi hanya 101,08 \%) dan peningkatan target pendapatan yang ditetapkan setiap tahun tidak besar karena tidak lebih dari $103 \%$ dari target pendapatan tahun sebelumnya. Kondisi tersebut menggambarkan bahwa pasar daerah potensinya sangat kecil untuk dapat dikembangkan pengelolaannya menjadi Perusahaan Daerah Pasar.

Berdasarkan hasil analisis rasio kemandirian, rasio aktivitas, rasio belanja modal, rasio pertumbuhan, evaluasi ekonomi, evaluasi efisiensi dan evaluasi efektivitas diketahui bahwa pasar daerah potensinya sangat kecil untuk di kembangkan pengelolaannya menjadi Perusahaan Daerah Pasar, tetapi berdasarkan analisis rasio ekuitas pasar daerah berpotensi untuk dikembangkan menjadi Perusahaan Daerah Pasar.

\section{Rasio Keuangan dan Kinerja Keuangan yang Perlu Ditingkatkan}

Perhatian terhadap peningkatan rasio keuangan dan evaluasi kinerja keuangan Dinas Pasar berdasarkan hasil analisis tersebut diatas, difokuskan pada beberapa hal sebagai berikut.

a. Keuangan pasar daerah belum mandiri, karena ketergantungan terhadap bantuan dana dari pemerintah daerah masih besar. Tabel 4 merupakan perhitungan terhadap dana bantuan pemerintah daerah berdasarkan selisih antara pendapatan retribusi dan belanja menujukkan bahwa pendapatan retribusi lebih kecil dari belanja. Keuangan pasar daerah dapat menjadi mandiri apabila pendapatan lebih besar dari belanja, sehingga tidak ada bantuan dari pemerintah daerah, bahkan dimungkinkan untuk membantu pemerintah daerah melalui laba yang dihasilkannya. 
b. Aktivitas Dinas Pasar masih rendah, karena komposisi penggunaan anggaran untuk belanja tidak langsung jauh lebih besar dibandingkan untuk belanja langsung. Aktivitas Dinas Pasar bisa menjadi tinggi apabila pendapatan lebih besar dari belanja sehingga alokasi dana bisa digunakan untuk meningkatkan anggaran belanja langsung.

c. Belanja modal pasar daerah masih rendah, karena alokasi untuk belanja modal masih sangat kecil. Belanja modal Dinas Pasar menjadi besar apabila pendapatan lebih besar dari belanja sehingga alokasi dana bisa digunakan untuk meningkatkan kegiatan belanja pembangunan fisik sarana prasarana.

d. Pertumbuhan pasar daerah rendah, karena pertumbuhan pendapatan retribusi pasar daerah lebih rendah dari pertumbuhan belanja. Pertumbuhan pasar daerah menjadi tinggi apabila peningkatan pendapatan lebih besar daripada peningkatan belanja.

e. Kinerja keuangan Dinas Pasar tidak efisien, karena pendapatan retribusi lebih kecil dari belanja. Pengelolaan keuangan menjadi efisien, apabila pendapatan lebih besar dari belanja.

Memperhatikan hasil analisis tersebut diatas diketahui bahwa peningkatan hasil analisis rasio keuangan dan hasil evaluasi kinerja keuangan pada dinas pasar sangat tergantung pada peningkatan pendapatan dan penurunan belanja.

\section{KESIMPULAN DAN SARAN}

\section{Kesimpulan}

Berdasarkan analisis rasio keuangan terhadap data keuangan Dinas Pasar dapat disimpulkan bahwa pasar daerah belum mandiri, aktivitas dalam pelaksanaan kegiatan berupa penyediaan sarana prasarana pasar daerah masih rendah, belanja modal untuk kegiatan pembangunan fisik sangat rendah, pertumbuhan belanjanya lebih tinggi dari pertumbuhan pendapatan. Namun demikian, rasio ekuitasnya menggambarkan pasar daerah dapat membiayai kebutuhan asetnya dengan kemampuan sendiri. Evaluasi kinerja keuangan pada Dinas Pasar berdasarkan value for money dapat disimpulkan bahwa realisasi belanja selalu lebih rendah dari anggaran belanja (ekonomi), realisasi 
pendapatan retribusi selalu lebih besar dari target pendapatan retribusi (efektif), tetapi realisasi pendapatan retribusi tersebut selalu jauh lebih rendah dari realisasi belanja (tidak efisien).

Perbedaan hasil analisis tersebut menggambarkan bahwa aset yang telah dimiliki pasar daerah pada saat ini bisa menjadi modal dasar untuk mengembangkan pengelolaannya menjadi perusahaan daerah pasar dengan catatan adanya peningkatan terhadap beberapa rasio keuangan tersebut. Analisis rasio terhadap kinerja keuangan pada satuan kerja perangkat daerah masih jarang dilakukan, karena sistim akuntansi baru dilaksanakan setelah diterbitkannya Peraturan Pemerintah nomor 24 Tahun 2005 tentang Standar Akuntansi Pemerintahan. Analisis rasio keuangan yang digunakan peneliti terdahulu untuk menganalisis kinerja keuangan pemerintah daerah dapat diterapkan untuk menganalisis kinerja keuangan satuan kerja perangkat daerah.

Keterbatasan pada penelitian ini adalah belum adanya peraturan pemerintah yang menetapkan standar wajar untuk mengukur hasil analisis kinerja keuangan baik di tingkat pemerintah daerah maupun satuan kerja perangkat daerah. Standar wajar yang digunakan dalam menganalisis kenerja keuangan pasar daerah dalam penelitian ini didasarkan pada literatur-literatur manajemen keuangan yang dikaji oleh Halim (2002) dan Mahmudi (2005).

\section{Saran}

Berdasarkan pengamatan langsung terhadap keberadaan pasar daerah, manajemen pasar daerah dan sistem pengelolaan keuangannya, maka ada beberapa bahan pertimbangan untuk meningkatkan pendapatan dan menurunkan belanja sebagai berikut : (1) Meningkatkan potensi pendapatan retribusi yang berkaitan secara langsung dengan pemanfaatan lahan pasar daerah, baik yang berupa jumlah pedagang, luas pemakaian lahan maupun jenis retribusi yang bisa dikenakan, (2) Melakukan penataan lingkungan pasar, (3) Meningkatkan akses ke pasar melalui kemudahan transportasi, (4) Sosialisasi peraturan daerah, (5) Menyederhanakan struktur organisasi Dinas Pasar 


\section{DAFTAR PUSTAKA}

Anoraga, Wien's, 2004, Kamus Istilah Ekonomi, penerbit M2S, Bandung;

Darise, Nurlan, 2011, Pengelolaan Keuangan pada Satuan Kerja Perangkat Daerah, penerbit PT. Indeks, Jakarta;

Bastian, Indra, 2006, Sistem Akuntansi Sektor Publik, penerbit Salemba Empat, Jakarta; Jogjakarta;

2006, Telaah Kritis PP 24 Tahun 2005, penerbit BPFE UGM,

Departemen Dalam Negeri Republik Indonesia, 2006, Peraturan Menteri Dalam Negeri No. 13 tahun 2006, tentang Pedoman Pengelolaan Keuangan Daerah, Jakarta;

Departemen Keuangan Republik Indonesia, 2005, Teori dan Aplikasi Keuangan Publik, Jakarta;

Departemen Keuangan Republik Indonesia, 2006, Audit Sektor Publik, Jakarta;

Djarwanto, Pangestu Subagyo, 1996, Statistik Induktif, penerbit BPFE UGM, Yogyakarta;

Halim, Abdul, 2002, Akuntansi Sektor Publik Akuntansi Keuangan Daerah, penerbit Salemba Empat, Jakarta; Jogjakarta;

Hanafi, Mamduh M, 2004, Manajemen Keuangan, penerbit BPFE UGM, Jogjakarta;

Mardiasmo, 2002, Akuntansi Sektor Publik, penerbit Andi, Jogjakarta;

Mahmudi, 2005, Manajemen Kinerja Sektor Publik, penerbit UPP AMP YKPN, Jogjakarta; Jogjakarta;

Pemerintah Republik Indonesia, 1997, Undang-undang No. 18 tahun 1997, tentang Pajak Daerah dan Retribusi Daerah, Jakarta;

Pemerintah Republik Indonesia, 2007, Undang-undang No. 17 tahun 2003, tentang Keuangan Negara, Jakarta;

Pemerintah Republik Indonesia, 2004, Undang-undang No. 1 tahun 2004, tentang Perbendaharaan Negara, Jakarta;

Pemerintah Republik Indonesia, 2004, Undang-undang No. 25 tahun 2004, tentang Sistim Perencanaan Pembangunan Nasional, Jakarta;

Pemerintah Republik Indonesia, 2004, Undang-undang No. 32 tahun 2004, tentang Pemerintahan Daerah, Jakarta; 
Pemerintah Republik Indonesia, 2004, Undang-undang No. 33 tahun 2004, tentang Perimbangan Keuangan antara Pemerintah Pusat dan Pemerintah Daerah, Jakarta;

Pemerintah Republik Indonesia, 2005, Peraturan Pemerintah No. 24 tahun 2005, tentang Standar Akuntansi Pemerintahan, Jakarta;

Pemerintah Republik Indonesia, 2005, Peraturan Pemerintah No. 56 tahun 2005, tentang Sistim Informasi Keuangan Daerah. Jakarta;

Pemerintah Republik Indonesia, 2005, Peraturan Pemerintah No. 58 tahun 2005, tentang Pengelolaan Keuangan Daerah. Jakarta;

Pemerintah Republik Indonesia, 2007, Peraturan Pemerintah No. 41 tahun 2011, tentang Organisasi Perangkat daerah, Jakarta;

Pemerintah Kabupaten Pasuruan, 2001, Peraturan Daerah Kabupaten Pasuruan Nomor 14 Tahun 2001 tentang Retribusi Pasar, Pasuruan;

Pemerintah Kabupaten Pasuruan, 2001, Peraturan Daerah Kabupaten Pasuruan Nomor 35 Tahun 2001 tentang Susunan Organisasi Dinas Daerah, Pasuruan;

Pemerintah Kabupaten Pasuruan, 2002, Keputusan Bupati Pasuruan Nomor 26 Tahun 2002 tentang Organisasi dan Tata Kerja Dinas Pasar Kabupaten Pasuruan, Pasuruan;

Sanusi, Anwar, 2003, Metodologi Penelitian Praktis untuk Ilmu Sosial dan Ekonomi, penerbit Buntara Media, Malang;

Santoso, Singgih, 2000, Mengolah Data Statistik secara Profesional, penerbit PT. Gramedia, Jakarta;

Sumarni, Murti dan John Soeprihanto, 1995, Pengantar Bisnis (Dasar-dasar Ekonomi Perusahaan), penerbit Liberty, Yogyakarta; 